\title{
Viscario vulgaris-Quercetum petraeae Stöcker (1965) in the Opawskie Mts (Eastern Sudetes)
}

\author{
Arkadiusz Nowak \& Sylwia Nowak
}

\begin{abstract}
Viscario vulgaris-Quercetum petraeae Stöcker (1965) in the Opawskie Mts (Eastern Sudetes). - Acta Mus. Siles. Sci. Natur., 64: 155-161, 2015.

Abstract: Results of phytosociological studies conducted in the southern part of Opole Silesia within the Sudetes mountain range in 2014-2015 are presented. The main aim of our research was to confirm the occurrence of Viscario vulgaris-Quercetum petraeae Stöcker 1965, which had previously been noted in Poland only within the Central Sudetes Foothills in Lower Silesia province. Two additional sites of this extremely rare in Poland plant association were confirmed, located within the Opawskie Mts in Opole province. The association develops on steep slopes, near rocky outcrops, on southern or western expositions at altitudes between 350 and $410 \mathrm{~m}$ a.s.l. All plots of the association consists of several diagnostic taxa and the share of thermophilous plants is clear. The Viscario vulgaris-Quercetum petraeae is rather species poor forest phytocoenosis with the herb layer abundance shrink by a scree downslides. The most frequent taxa contributing to the sampled plots were: Luzula luzuloides, Galeopsis ladanum, Hieracium laevigatum, Lembotropis nigricans, Vaccinium myrtillus, Deschampsia flexuosa and Viscaria vulgaris. In all forest plots the Quercus petraea apparently dominates and shrub layer is scarce.
\end{abstract}

Key words: Opole province, dry oak forest, endangered phytocoenoses, SW Poland

\section{Introduction}

Acidophilous forests with domination of oaks have attracted European phytosociologists from the early beginning of the geobotanical studies (e.g. Paczoski 1926, 1930; Libbert 1933; Soó 1934). Until know, several synthetic works present the diversity and distribution of this vegetation type in the majority of the Central European countries, in this in the neighbouring areas of Silesia (e.g. Pott 1995; Moravec 1998; Willner \& Grabherr 2007; Roleček 2013). This regards also Poland with the summarizing works of Matuszkiewicz \& Matuszkiewicz (1956), J.M. Matuszkiewicz (1988, 2007), Matuszkiewicz \& Kozłowska (1991), Kasprowicz (2010). However the association of Viscario vulgaris-Quercetum petraeae was firstly mentioned just recently by Reczyńska (2015).

In eastern Sudetes the oak forests have been subjected to geobotanical studies for more than 40 years, however there are still some gaps in knowledge. Only some works focused on general issues of wood communities (Kuczyńska 1973), or on particular forest phytocoenoses like e.g. Molinio arundinaceae-Quercetum Samek 1962 (Celiński \& Wika 1974-1975; Matuszkiewicz J.M. 2001; Matuszkiewicz W. 2001; Nowak S. \& Nowak A 2008) or Aceri platanoidis-Tilietum platyphylli Faber 1936 (Nowak A. \& Nowak S. 2008a) were reported. The last comprehensive research on acidophilous oak forests was conducted by Reczyńska (2015). In her research the Viscario vulgaris-Quercetum petraeae was mentioned for the first time for Poland, with stands found in Central part of Sudety range.

The association of acidophilous, dry and thermophilous oak forest was firstly described by Stöcker (1965) from Harz Mts in Saxony. It is known also from Czech Republic (Moravec 1998; Kolbek et al. 2003; Roleček 2013) and Slovakia (Jarolímek et al. 2008). This type of Quercus petraea forests is related to mineral-poor substrates and shallow ranker-type soils on schales, siltstones or conglomerates. It prefers warm stands on steep slopes with southern to western expositions in colline and submontane altitudinal zones, mainly between $300-550 \mathrm{~m}$ 
a.s.l. All known stands are apparently dominated by Quercus petraea with only sporadic occurrence of Pinus sylvestris, Tilia cordata, Acer platanoides or A. pseudoplatanus. Shrub layer consists mainly of the canopy species with some additional taxa like Crataegus sp. and Rosa sp. In comparison to other acidophilous oak forests, the share of thermophilous species is considerably higher. Such taxa as Cytisus nigricans, Viscaria vulgaris, Genista tinctoria, Festuca ovina and Sedum maximum, frequently contribute to this association. The diagnostic species designed for the Viscario-Quercetum are Quercus petraea, Cytisus nigricans, Festuca ovina, Galeopsis ladanum, Genista germanica, G. tinctoria, Hieracium laevigatum, $H$. sabaudum, Jasione montana, Luzula luzuloides, Silene nutans, Veronica officinalis and Viscaria vulgaris. As constant species Quercus petraea, Deschampsia flexuosa, Campanula rotundifolia, Cytisus nigricans, Festuca ovina, Genista tinctoria, Hieracium lachenalii, $H$. murorum, H. sabaudum, Luzula luzuloides, Poa nemoralis, Silene nutans, Veronica officinalis, Hieracium pilosella and Viscaria vulgaris were indicated (Roleček 2013; Reczyńska 2015).

In a forested landscape, the association of Viscario-Quercetum occurs adjacent to other acidophilous oak stands like Luzulo luzuloidis-Quercetum, Molinio arundinaceae-Quercetum and rarely Luzulo-Fagetum or Calamagrostio arundinaceae-Quercetum.

The aim of this communication is to complete the knowledge about acidophilous dry oak forests in Sudetes Mts and present its current distribution and floristic composition in Opole province.

\section{Methods}

The geobotanical researches were conducted in southern part of the Opole Silesia within the range of the Sudetes Mts. where the forested screes or steep slopes with underdeveloped, acidic soil were noted (Fig 1). The studies were carried out in 2014-2015. As phenological aspects were also considered in the fieldwork, basic investigations were conducted in September. Two areas and nine vegetation plots with acidophilous dry oak forests were sampled using the phytosociological Braun-Blanquet approach (1964). Due to community physiognomy and the homogeneity of vegetation, we took relevés with a surface of $200 \mathrm{~m}^{2}$. In each relevé, all vascular plant species and mosses were recorded using the seven-degree coverabundance scale of Braun-Blanquet (Westhoff \& van der Maarel 1973). For each plot, geographical coordinates were measured with the help of a GPSMAP 60CSx device with an accuracy of $\pm 5 \mathrm{~m}$, using the WGS84 reference frame. In the table, latitude and longitude are given in degrees, minutes and seconds. Rock type was determined through an analysis of lithology, pore geometry, texture and hardness. The species nomenclature follows Mirek et al. (2002).

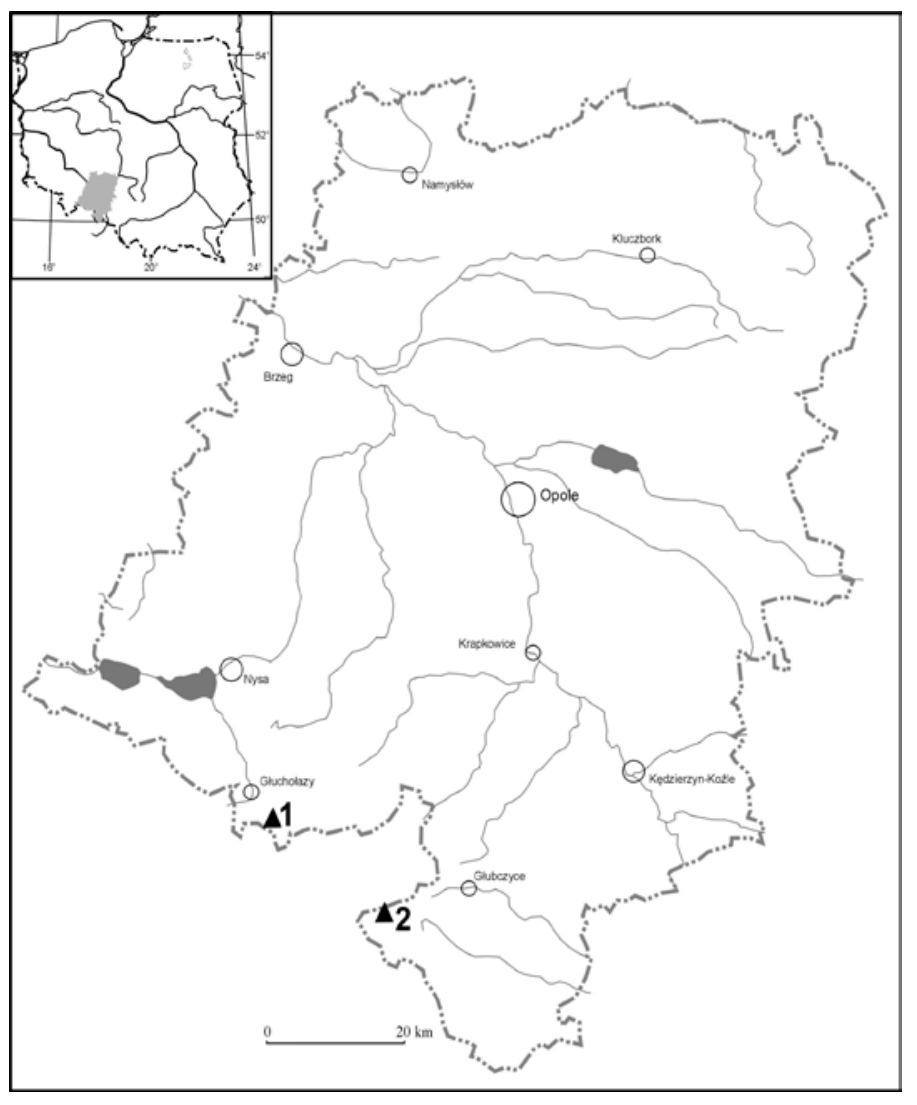
The syntaxonomical classification and name of the syntaxa are used in accordance to Roleček (2013) and Matuszkiewicz (2001).

Fig 1: Distribution of Viscario vulgaris-Quercetum petraeae Stöcker (1965) association in the Opawskie Mts (Opole province): 1 - Jarnołtówek, 2 - Pielgrzymów 


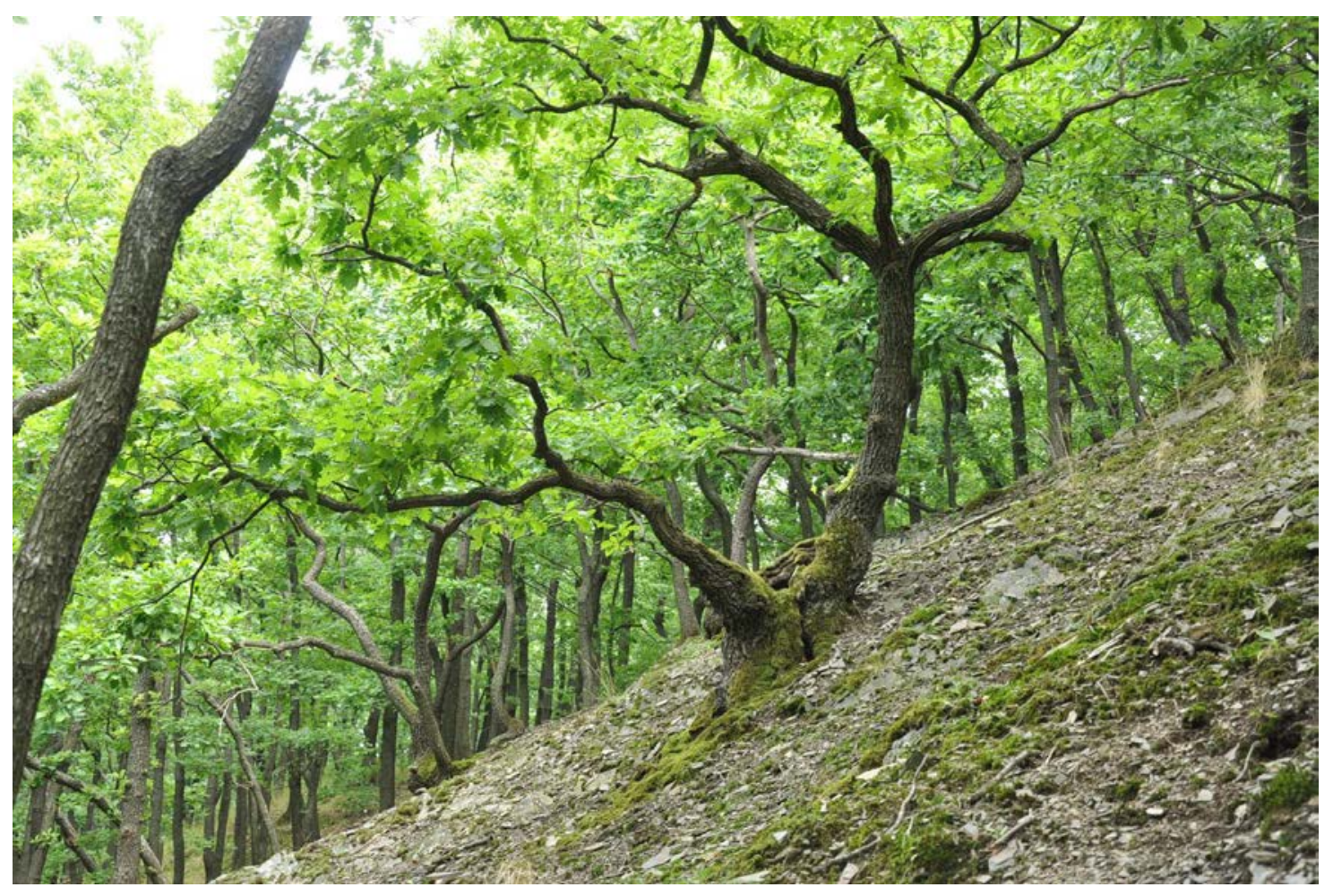

Fig 2: Stand of Viscario vulgaris-Quercetum petraeae near Pielgrzymów in the Mokre-Lewice Landscape Protection Zone.

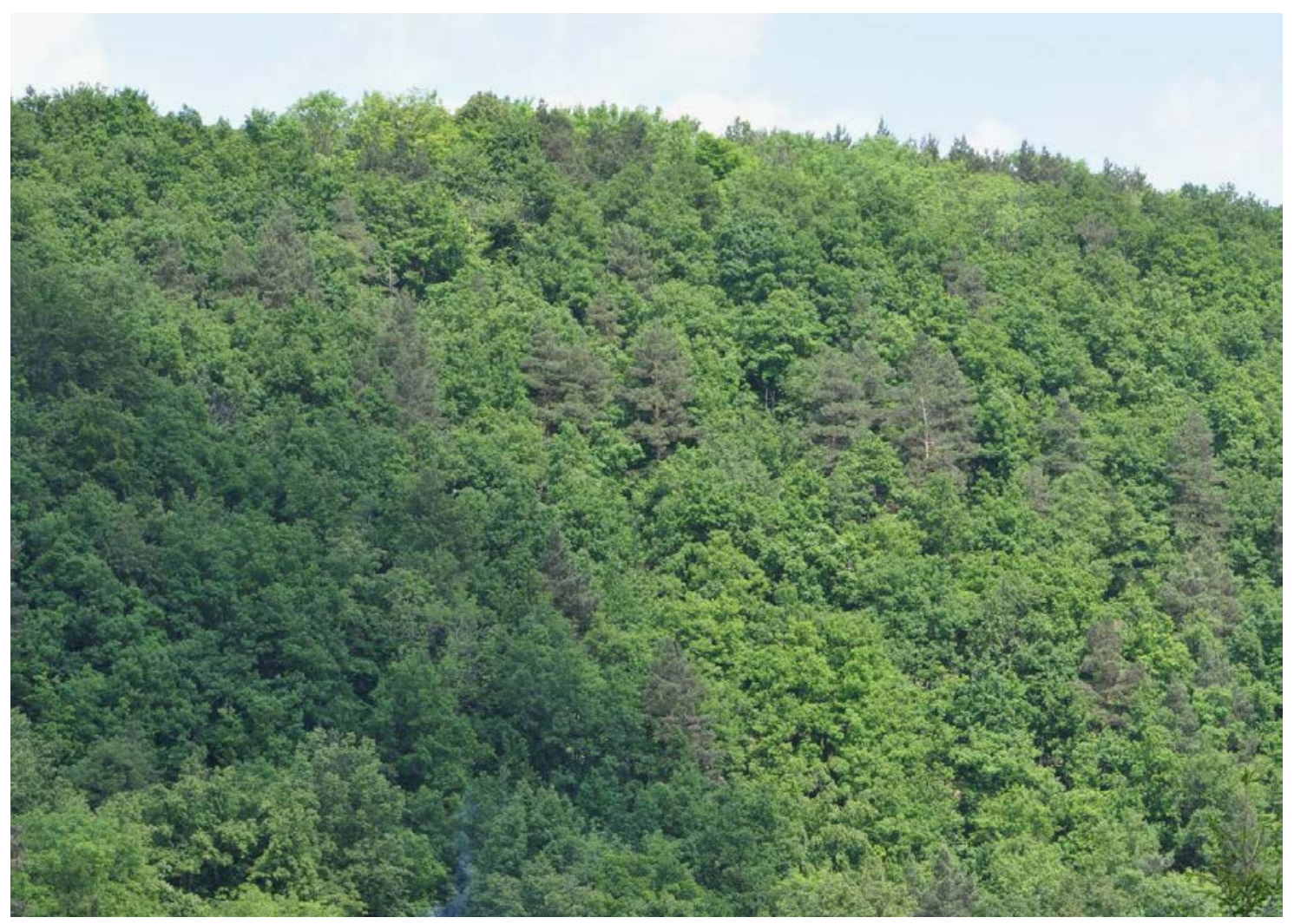

Fig 3: The Olszak Hill with "Karolinki" outcrops between Jarnołtówek and Pokrzywna - the main occurrence area of Viscario vulgaris-Quercetum petraeae. 


\section{Results}

Our studies confirm the presence of the association Viscario vulgaris-Quercetum petraeae Stöcker (1965) within the southern part of Opole Silesia. Two sites of that phytocenosis were found, one of them located on the slopes of Karolinki Rocks in Złoty Potok River valley, the second near the Pielgrzymów village in the easternmost hills of Sudety range (Fig 1).

Viscario vulgaris-Quercetum petraeae occupies small areas on poorly developed soil substrates in upper parts of river valley gorges or on steep slopes with scree-like rupicolous habitat. The plots with the association often neighbours with rock outcrops of phyllitic shales and schists. The altitudinal amplitude of sampled plots were approx. 350 - $410 \mathrm{~m}$ a.s.l. (Table 1). The largest area extent of the association was noted on the southern slopes of Olszak Mt. (so called Karolinki rocks). It spreads alongside upper outcrops line at the elevation of approx. $400 \mathrm{~m}$ a.s.l. The Viscario-Quercetum prefers southern exposition with some stands facing south-western and western ones. Species richness in sampled plots was between 12 and 20 (Table 1).

The dominant species in canopy is Quercus petraea with the cover of $45-75 \%$ in particular plot and insignificant share of Pinus sylvestris, Betula pendula and Tilia cordata. Shrub layer is not so abundant (1-15\%) and consists mainly of small trees. Also the herbaceous layer is not species rich and dense having on average approx. 65\% cover. Especially on steepest slopes, the herbs cover is scarce. The most frequent species contributing to the sampled plots were Luzula luzuloides, Galeopsis ladanum, Hieracium laevigatum, Lembotropis nigricans, Vaccinium myrtillus, Deschampsia flexuosa, Viscaria vulgaris, Calluna vulgaris, Calamagrostis arundinacea, Sedum maximum, Genista tinctoria and Festuca ovina. The representation of diagnostic taxa for the association is fairly numerous and comprise of eleven species (Table 1). The moss layer is well developed in some plots, reaching up to 35\% with Polytrichum piliferum and Hypnum cupressiformae as the main components.

\section{Discussion}

The newly found plots of Viscario vulgaris-Quercetum petraeae in Opole province have considerable importance from biogeographical point of view, because they widen the range of this association in Central Europe to the north-east of ca. $100 \mathrm{~km}$. The plots studied are well developed reflecting the typical floristic composition of the association if compared to plots known from Czech Republic or central part of Sudetes Mts in Poland (Roleček 2013; Reczyńska 2015). The most suitable conditions for the growth of this association are found in the Olszak Hill in main section of Opawskie Mts in Jarnołtówek village. The very steep, southern slopes with down sliding screes make the condition for canopy development fairly hard, making the tree layer loose and allowing the colonisation of thermophilous species. Light demanding taxa, with the diagnostic Viscaria vulgaris, Sedum maximum or Silene vulgaris could thrive in those conditions.

The Viscario vulgaris-Quercetum petraeae was found in Opawskie Mts, however in its lower zone - submontane. This is the reason, that within plots almost no typical montane or alpine species were noted. In contrary, many lowland plants, especially related to dry habitats were noted. Examples are Calamagrostis arundinacea, Lysimachia vulgaris, Jasione montana, Veronica officinalis, Polygonatum odoratum and others. However there are also typical montane species which predominate in herbaceous layer. The most frequent is Luzula luzuloides which occurs in considerable abundances in all plots. 
As regards the synanthropic state of the association, despite the close contact with urbanized areas, the researched plots don't reflect the considerable changes due to alien or ruderal species colonisation. Only in few cases, when the plot was located close to tourist trails or paths, an insignificant share of Galeopsis pubescens was noted.

The main indicator of the association within all acidophilous woods that surround the researched plots are the share of thermophilous species and the habitat features, especially the scree-like colluvial deposits of stone debris. This makes the association clearly distinct as compared to Calamagrostio arundinaceae-Quercetum or Luzulo luzuloidis-Quercetum.

The association of Viscario vulgaris-Quercetum petraeae has crucial conservation importance. It develops in a very restricted area in south-west Poland and on approx. 2 ha in Opole province. It needs special attention of forest and nature conservation administrations. It should be also included into the list of threatened plant communities of Opole province (Nowak A. \& Nowak S. 2008b)

\section{References}

Braun-Blanquet J. (1964): Pflanzensoziologie, Grundzüge der Vegetationskunde. 3 Aufl. - Springer Verlag, Wien - New York, 865 pp.

Celiński F. \& Wika S. (1974-1975): Zespoły leśne projektowanego rezerwatu w Rozumicach w pow. głubczyckim. - Zeszyty Przyrodnicze 14-15: 23-42.

Jarolímek I., Šibík J., Hegedüšová K. et al. (2008): A list of vegetation units of Slovakia. In: Jarolímek I. \& Šibík J. [eds]: Diagnostic, constant and dominant species of the higher vegetation units of Slovakia, Veda, Bratislava, pp. 295-329.

Kasprowicz M. (2010): Acidophilous oak forests of the Wielkopolska region (West Poland) against the background of Central Europe. - Biodiversity Research and Conservation 20: 1-138.

Kolbek J., Bílek O. \& Boublík K. et al. (2003): Vegetace Chráněné krajinné oblasti a Biosférické rezervace Křivoklátsko 3. Společenstva lesů, křovin, prameništ', balvaništ' a acidofilních lemů. Academia, Praha.

Kuczyńska I. (1973): Stosunki geobotaniczne Opolszczyzny. I. Zbiorowiska leśne. - Acta Univ. Wrat. 162. Prace Bot. 15: 1-91.

Libbert W. (1933): Die Vegetationseinheiten der neumärkischen Staubeckenlandschaft unter Berücksichtigung der angrenzenden Landschaften. - Verhandlungen des Botanischen Vereins der Provinz Brandenburg 75: 229-348.

Matuszkiewicz J.M. (2001): Zespoły leśne Polski. - Wydawnictwo Naukowe PWN, Warszawa, 358 pp.

Matuszkiewicz W. (2001): Przewodnik do oznaczania zbiorowisk roślinnych Polski. Vademecum Geobotanicum 3. - Wydawnictwo Naukowe PWN, Warszawa, 537 pp.

Matuszkiewicz J.M. \& Kozłowska A.B. (1991): Przegląd fitosocjologiczny zbiorowisk leśnych Polski ciepłolubne dąbrowy. - Fragmenta Floristica et Geobotanica 36: 203-256.

Matuszkiewicz J.M. (1988): Przegląd fitosocjologiczny zbiorowisk leśnych Polski. Bory mieszane i acidofilne dąbrowy. - Fragmenta Floristica et Geobotanica 32: 107-184.

- (2007): Zespoły leśne Polski. - Wydawnictwo Naukowe PWN, Warszawa.

Matuszkiewicz W. \& Matuszkiewicz A. (1956): Materiały do fitosocjologicznej systematyki ciepłolubnych dąbrów w Polsce. - Acta Societatis Botanicorum Poloniae 25: 27-72.

Mirek Z., Piękoś-Mirkowa H., Zając A. \& Zając M. (2002): Flowering Plants and pteridophytes of Poland - a checklist. In: Mirek Z. (red.), Biodiversity of Poland 1. W. Szafer Institute of Botany, Polish Academy of Science, Kraków, 442 pp.

Moravec J. (1998): Acidofilni doubravy. Vol. 1. Přehled vegetace České republiky. Academia Praha, 63 pp.

Nowak A. \& Nowak S. (2008a): Aceri platanoidis-Tilietum platyphylli Faber 1936 association in the Opole Silesia. In: Kočárek P., Plášek V., Malachová K. (eds), 2008: Environmental changes and biological assessment IV. - Scripta Facultatis Rerum Naturalium Universitatis Ostraviensis 186: 290-294.

- (2008b): Anthropogenic changes of Opole Silesia plant cover (Poland, Central Europe). pp. 77-98. In: Nowak A., Nobis M., Kusza G. (eds). Some aspects of nature conservation and environmental protection in Poland and Tajikistan. Stow. Ochr. Przyr BIOS, Opole, 201 pp.

Nowak S. \& Nowak A. (2008): Molinio arundinaceae-Quercetum petraeae Neuh. et Neuh.-Nov. 1967 association in the Eastern Sudeten. In: Kočárek P., Plášek V., Malachová K. (eds), 2008: Environmental changes and biological assessment IV. - Scripta Facultatis Rerum Naturalium Universitatis Ostraviensis 186: 295-300.

Paczoski J. (1926): Dąbrowy Białowieży. - Przegląd Leśniczy 11: 517-529, 12: 571-583.

- (1930): Lasy Białowieży. - Państwowa Rada Ochrony Przyrody, Poznań. 
Pott R. (1995): Die Pflanzengesellschaften Deutschlands. 2nd ed. - Eugen Ulmer Verlag, Stuttgart.

Reczyńska K. (2015): Diversity and ecology of oak forests in SW Poland (Sudetes Mts.). - Phytocoenologia 45: 85-106.

Roleček J. (2005): Vegetation types of dry-mesic oak forests in Slovakia. - Preslia 77: 241-261.

Soó R. (1934): Magyarország erdőtipusai. Összehasonlító erdei vegetáció-tanulmányok, II. - Erdészeti Kisérletek 36: 86-138.

Stöcker G. (1965): Vorarbeit zu einer Vegetationsmonographie des Naturschuztgebietes Bodetal. II. Waldgesellschaften. Wiss. Z. Martin-Luther-Univ. Halle-Wittenberg. - Math.-Naturwiss. Reihe. 14/65: 505561.

Westhoff V. \& van der Maarel E. (1973): The Braun-Blanquet approach. - Handbook of Vegetation Science 5: 619-726.

Willner W. \& Grabherr G. (eds) (2007): Die Wälder und Gebüsche Österreichs. Ein Bestimmungswerk mit Tabellen. Spektrum Akademischer Verlag, München.

Authors‘ addresses: Arkadiusz Nowak, Department of Biosystematics, Laboratory of Geobotany \& Plant Conservation, University of Opole, ul. Oleska 22, 45-052 Opole, Poland and Department of Biology and Ecology, University of Ostrava, 71000 Ostrava, Czech Republic

E-mail: anowak@uni.opole.pl

Sylwia Nowak, Department of Biosystematics, Laboratory of Geobotany \& Plant Conservation, University of Opole, ul. Oleska 22, 45-052 Opole, Poland

E-mail: snowak@uni.opole.pl

\section{Appendix:}

\section{Table 1. Viscario vulgaris-Quercetum petraeae Stöcker 1965}

Relevé number

day

Date: month

year

Inclination (degrees)

Altitude (m)

Density of tree layer a (\%)

Density of shrub layer b (\%)

Cover of herb layer c (\%)

Cover of moss layer $d(\%)$

Exposition

Relevé area $\left(\mathrm{m}^{2}\right)$

Locality

Number of species

$\begin{array}{ccccccccc}1 & 2 & 3 & 4 & 5 & 6 & 7 & 8 & 9 \\ 21 & 24 & 24 & 24 & 24 & 24 & 1 & 1 & 1 \\ 6 & 7 & 7 & 7 & 7 & 7 & 8 & 8 & 8 \\ 2014 & 2015 & 2015 & 2015 & 2015 & 2015 & 2015 & 2015 & 2015 \\ 45 & 35 & 35 & 40 & 35 & 35 & 40 & 35 & 30 \\ 411 & 393 & 382 & 388 & 382 & 380 & 353 & 354 & 352 \\ 50 & 55 & 70 & 50 & 75 & 65 & 70 & 50 & 70 \\ 5 & 10 & 1 & 15 & 15 & 5 & 1 & - & - \\ 55 & 75 & 55 & 70 & 75 & 60 & 55 & 55 & 50 \\ 35 & 10 & 5 & - & 20 & - & 30 & - & - \\ \mathrm{S} & \mathrm{S} & \mathrm{S} & \mathrm{S} & \mathrm{S} & \mathrm{S} & \mathrm{W} & \mathrm{SW} & \mathrm{SW} \\ 200 & 200 & 200 & 200 & 200 & 200 & 200 & 200 & 200 \\ \mathrm{~J} & \mathrm{~J} & \mathrm{~J} & \mathrm{~J} & \mathrm{~J} & \mathrm{~J} & \mathrm{P} & \mathrm{P} & \mathrm{P} \\ 15 & 15 & 14 & 16 & 18 & 20 & 13 & 12 & 15\end{array}$

Trees and shrubs

Quercus petraea a

Quercus petraea b

Quercus petraea c

Pinus sylvestris a

Pinus sylvestris c

Sorbus aucuparia b

Sorbus aucuparia c

Sarothamnus scoparius b

Sarothamnus scoparius c

Tilia cordata a

Corylus avellana $\mathrm{b}$

$\begin{array}{cccccccccc}3 & 3 & 4 & 3 & 4 & 3 & 4 & 3 & 4 & \text { V } \\ 1 & 1 & & 1 & 1 & 1 & & & & \text { III } \\ 1 & & 1 & & 1 & + & + & & + & \text { IV } \\ & 1 & & 1 & & 2 & & & & \text { III } \\ + & & + & & & & & & \\ & + & + & & 1 & + & + & & & \text { II } \\ + & & & & 1 & & & + & + & \text { III } \\ 1 & 1 & & 1 & & & & & & \text { II } \\ & & & + & + & + & & & \\ & & & & + & 1 & & & \text { II } \\ & & + & & + & & & \text { II }\end{array}$




\begin{tabular}{|c|c|c|c|c|c|c|c|c|c|c|}
\hline \multicolumn{3}{|l|}{ Carpinus betulus b } & & 1 & + & & & & & II \\
\hline \multicolumn{3}{|l|}{ Carpinus betulus c } & + & & & & & & & I \\
\hline \multicolumn{3}{|l|}{ Frangula alnus b } & & + & 1 & + & & & & II \\
\hline \multicolumn{3}{|l|}{ Betula pendula a } & & & & 1 & & & & I \\
\hline \multicolumn{3}{|l|}{ Fagus sylvatica b } & + & & & & & & & I \\
\hline \multicolumn{3}{|l|}{ Acer platanoides b } & & & & + & & & & I \\
\hline \multicolumn{11}{|c|}{ Ch, D. Ass. Viscario vulgaris-Quercetum } \\
\hline Luzula luzuloides & 1 & 2 & 2 & 2 & 2 & 3 & 2 & 2 & 2 & $\mathrm{~V}$ \\
\hline Galeopsis ladanum & + & + & 1 & + & + & + & + & 1 & + & $\mathrm{V}$ \\
\hline Hieracium laevigatum & 1 & + & & 1 & 1 & 1 & & 1 & 1 & IV \\
\hline Lembotropis nigricans & + & & + & + & & & + & + & + & IV \\
\hline \multicolumn{2}{|l|}{ Viscaria vulgaris } & 1 & & 1 & + & 1 & & & & III \\
\hline \multicolumn{2}{|l|}{ Sedum maximum } & + & + & + & + & + & & & & III \\
\hline \multicolumn{2}{|l|}{ Genista tinctoria } & & & & + & & 1 & + & + & III \\
\hline \multicolumn{2}{|l|}{ Festuca ovina } & & & & & + & + & 2 & 1 & III \\
\hline \multicolumn{2}{|l|}{ Silene nutans } & & & & & & + & & 1 & II \\
\hline \multicolumn{2}{|l|}{ Jasione montana } & & & & & + & & & & I \\
\hline \multicolumn{4}{|c|}{ Veronica officinalis } & & & & & + & & I \\
\hline \multicolumn{11}{|c|}{$\begin{array}{l}\text { Ch. D.* All. Qercion robori-petraeae, Ch. O. Quercetalia robori-petraeae } \\
\text { et Ch. Cl. Quercetea robori petraeae }\end{array}$} \\
\hline Vaccinium myrtillus & 1 & 1 & 2 & 2 & & + & 1 & & & IV \\
\hline Deschampsia flexuosa & 2 & 3 & & & 1 & 1 & & & & III \\
\hline Calluna vulgaris & 2 & 1 & & & 1 & 1 & & & & III \\
\hline Calamagrostis arundinacea & 1 & 2 & 2 & 3 & 3 & & & & & III \\
\hline Hypnum cupressiformae & 2 & 1 & 1 & & 2 & & & & & III \\
\hline \multicolumn{3}{|l|}{ Polygonatum odoratum } & & & & & & 1 & 1 & II \\
\hline \multicolumn{3}{|l|}{ Digitalis grandiflora } & & & & & + & & 1 & II \\
\hline \multicolumn{3}{|l|}{ Hieracium murorum } & & & & & 2 & 1 & 1 & II \\
\hline \multicolumn{11}{|l|}{ Others } \\
\hline Bryum sp. & 2 & 1 & & & & & & & & II \\
\hline Galeopsis pubescens & + & & & & & & & & & I \\
\hline Polypodium vulgare & & & & + & & & 1 & & & II \\
\hline Cladonia sp. & & & & & 1 & 1 & & 1 & & II \\
\hline Poa nemoralis & & & & & & & 1 & & 1 & II \\
\hline $\begin{array}{l}\text { Sporadic species: Hypericun } \\
\text { 9, Campanula persicaria } 9 .\end{array}$ & & & & & & & & & & \\
\hline
\end{tabular}

